\title{
PROBLEMS, EXPECTATIONS, AND AMENDMENTS REGARDING DISTANCE EDUCATION LEGISLATION IN HIGHER EDUCATION INSTITUTIONS IN TURKEY
}

\author{
Dr. Munevver ESGICE GUNDUZ \\ ORCID: 0000-0003-1358-8803 \\ Department of Computer Education and Instructional Technologies \\ Ataturk University \\ Erzurum, TURKEY \\ Dr. Engin KURSUN \\ ORCID: 0000-0002-5649-8595 \\ Department of Computer Education and Instructional Technologies \\ Ataturk University \\ Erzurum, TURKEY \\ Dr. Selcuk KARAMAN \\ ORCID: 0000-0002-0493-3444 \\ Department of Computer Education and Instructional Technologies \\ Ataturk University \\ Erzurum, TURKEY \\ Dr. Turgay DEMIREL \\ ORCID: 0000-0001-9210-8876 \\ Faculty of Engineering \\ Igdir University, \\ Igdir, TURKEY
}

Received: 13/11/2019 Accepted: 23/05/2020

\begin{abstract}
This study's goal was to reveal amendments to the Procedures and Principles regarding Distance Education in Higher Education Institutions issued by the Higher Education Institution in Turkey, applications affected by these amendments, and problems and expectations at the system, program, and course levels. To this end, different versions of the Procedures and Principles regarding Distance Education in Higher Education Institutions were examined to determine the existing amendments to the Procedures and Principles and the areas affected by them. Eight individuals who had served as administrators in distance education centers of universities in Turkey for at least three years and who were selected by the purposive sampling method were interviewed to reveal expectations for the Procedures and Principles. This study was based on the qualitative research design. Document review and interview were used as data collection methods. The data were analyzed by content analysis. The analyses have shown that the amendments to the Procedures and Principles affect especially program and course opening, branching, assignment, and student admission practices. Within the scope of the study, distance education executives stated their expectations for issues such as program and course opening and the determination of supervisors, assignment procedures, and taking into account the course student coefficient in the calculation of course fees.
\end{abstract}

Keywords: Distance education, procedures and principles, distance education policies 


\section{INTRODUCTION}

Distance education is rapidly becoming widespread in higher education along with technological developments and offers completely new opportunities for learners. The features of distance education, such as providing opportunities for the economy, lifelong learning, and individual learning and being free from the limitations of traditional methods (flexibility, time and space dependency, etc.), are the main factors affecting this spread. Distance education refers to a comprehensive system that uses opportunities of communication technology and educational technology. Distance education is a type of education with many stakeholders, such as teachers, students, managers, policymakers, material developers, and technical support team. Furthermore, distance education centers are centers where all stakeholders work synergistically and create joint projects (Akan, 2012). The effectiveness of distance education institutions increases as these stakeholders within the system become more associated and united. Moore and Kearsley (2011) stated that distance education should be evaluated not only with the history, theory, educational, or organizational design but in a holistic way with the distance operation of the whole system. Aydin (2008) stated that students, instructors, managers, and employees play an essential role in the distance education system and argued that all components of the system and factors outside the system should be examined in detail.

Studies in the field of distance education appear to focus on direct teaching functions such as most in-class activities (Tesolin \& Tsinakos 2018) with stakeholders such as distance students (Sahin \& Shelley, 2008) and distance educators (Rabinovich, Berthon \& Fedorenko, 2017). However, another factor that has a direct effect on processes for distance education practices is legal regulations on to whom, under which conditions, and in what ways distance education will be provided. Legal regulations for distance education legislation are essential for distance education practices since distance education policies guide the development of distance education programs, provide a framework in functioning, and include a number of rules that define roles and responsibilities. While these policies sometimes include some guarantees of quality to improve quality and to make education more effective and efficient, they may sometimes consist of rules such as revealing the priorities, expenses, and investment costs of the institution, limiting the number of students, and limiting the number of courses (Zawacki-Richter and Qayyum, 2019).

Distance education policies established based on a country or an institution affect all components of the distance education system directly or indirectly. In their study conducted on distance education policies at the University of Argentina, Gonzalez and Roig (2018) emphasized that regulations led to the emergence of innovative practices and opened new horizons. Nevertheless, state-funded projects are carried out for distance education policies in Korea, and the legislation is updated every five years (MOE of Korea, 2015a). It appears that these policies play an essential role in the spread of distance education in distance education institutions in Korea (Lee, Lim, \& Lim, 2009). However, there are also studies emphasizing that policies adversely affect or slow down the spread of distance education. For example, Lim (2015) argued that the number of student admissions clearly defined by the policies of all institutions providing distance education in Korea, student election policy, and distance education did not support lifelong learning. Kim and Kim (2017) also emphasized that student assessments, qualifications of the teaching staff, curriculum, library and laboratory facilities, and the strict supervision of partnerships with other groups adversely affected the development of distance education. Likewise, access to distance education, price, quality, and information regulations are managed by government policies in China, which leads to the limitation of distance education practices. Nevertheless, Li, Zhang, Yu, and Chen (2014) highlighted the importance of determining the duties and responsibilities of distance education institutions in China by legal regulations. Shortcomings and gaps in distance education policies may also pose obstacles to distance education, lifelong learning opportunities, opportunity to reach more people, and alternative activities and methods (Zhang, Zheng, \& Yu, 2012). Muilenberg and Berge (2001) describe the most common problems in distance education under the headings of administrative structure, organizational changes, technical expertise, support and infrastructure, social interaction, payments, technology threat, copyright, evaluation/effectiveness, access, and student support systems. In Turkey Informatics Council Report (2002), it is stated that one of the most important barriers to the widespread of distance education is the inadequacy of the legislation. Thus, Akan (2012) also estimates that the project-based working logic in distance education centers will be replaced by bureaucratic and cumbersome functioning with the current legislation. Thus, distance education centers will be disabled in the medium term. 


\section{THE HISTORY OF LEGAL REGULATIONS ON DISTANCE EDUCATION IN TURKEY}

In Turkey, distance education studies started to be carried out in a certain order with the publication of the Regulation on Distance Education Based on Inter-university Communication and Information Technologies by the Council of Higher Education in 1999. This regulation ensured standardization at the point of implementation and conducting activities for distance education centers and higher education institutions to which they were affiliated. Afterward, the Informatics National Committee [Enformatik Milli Komitesi] was established on 14.12.1999 to plan educational opportunities and increase the efficiency of education in distance education and informatics fields based on communication and information technologies in higher education institutions. The Committee provides cooperation and coordination between higher education institutions and organizations in the field of informatics and distance education. At the same time, it conducts research, examination, and evaluations in cooperation with universities to increase the efficiency of education and plan educational opportunities in higher education institutions (Official Gazette, 2000).

In 2005, the Council of Higher Education (YOK) Distance Education Commission was established. Afterward, the Council of Higher Education issued the Procedures and Principles regarding Distance Education in Higher Education Institutions in 2013 and took an important step for the implementation of distance education in higher education institutions in Turkey. The legislation structure of distance education programs in higher education institutions was established based on these Procedures and Principles. In 2014, the Council of Higher Education decided to make some amendments to the mentioned Procedures and Principles. The aim of the Procedures and Principles regarding Distance Education in Higher Education Institutions was to determine procedures and principles related to opening distance education programs based on information and communication technologies in higher education institutions and teaching some courses in formal education through distance education. These procedures and principles involve areas in which distance education programs can be opened in higher education institutions, courses to be given through distance education and their credits, the preparation of course materials, the way of conducting examinations, protocols to be made for this purpose between higher education institutions, payments to be made, and other issues related to distance education (YOK, 2014).

\section{THE SCOPE OF THE PROCEDURES AND PRINCIPLES REGARDING DISTANCE EDUCATION IN HIGHER EDUCATION INSTITUTIONS}

The issues covered by the Procedures and Principles regarding Distance Education in Higher Education Institutions are presented in Figure 1 under general headings. 

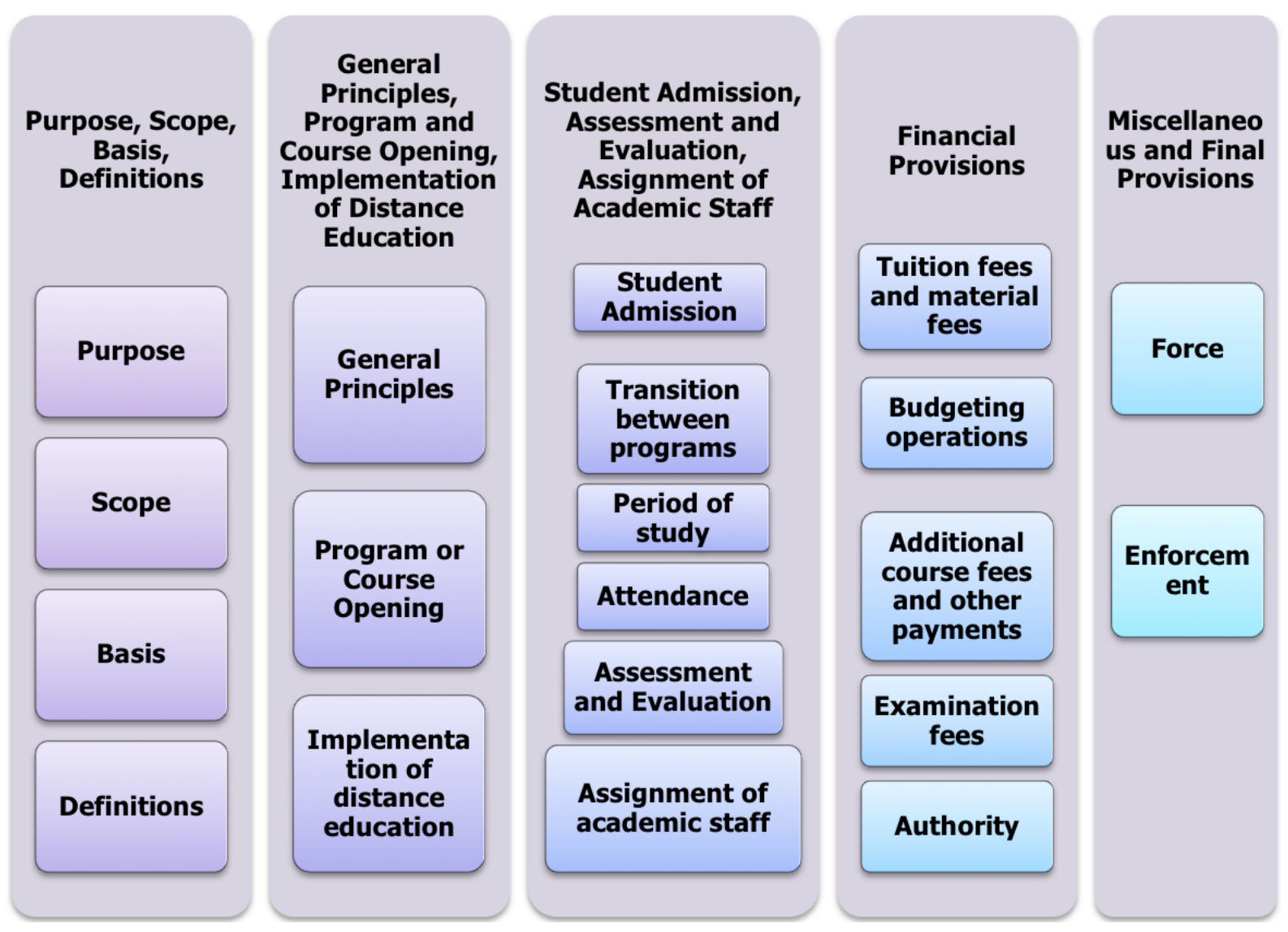

Figure 1. Issues Covered by the Procedures and Principles Regarding Distance Education in Higher Education Institutions

\section{Purpose, Scope, Basis and Definitions}

In the first section of the Procedures and Principles, the purpose, scope, and legal provisions of the Procedures and Principles are stated. Moreover, the expressions of the coefficients mentioned in the Procedures and Principles (the unit student coefficient, the program student coefficient, and the course student coefficient), the payment information to be determined and taken into consideration in payments (material fee, tuition fee), and definitions of the unit, board, and commissions are made.

\section{General Principles, Program and Course Opening, Implementation of Distance Education}

a. General Principles: In this section, the basic principles of distance education practices are discussed.

b. Program or course opening: Under this heading, criteria that will be taken into consideration when opening a program or course in distance education were determined and discussed. The dates of the submission of proposals for program and course opening to the Council of Higher Education, quotas, criteria for academic cooperation between higher education institutions, what part of a course can be carried out distantly, and information on the execution of the promotion activities of a distance course or program are given in this section.

c. Implementation of Distance Education: The criteria for branching courses taught distantly are presented in this section. The number of students in each branch according to the program level and the maximum number of branches that faculty members can manage were presented. 


\section{Student Admission, Assessment and Evaluation, Assignment of Academic Staff}

a. Student Admission: The criteria for procedures of taking courses in distance education are explained in this section.

b. Transition between programs: The regulation governing the transition between distance education programs is specified in this section.

c. Period of study: The article of the law to which the periods of study in distance education programs are subject is stated under this heading.

d. Compulsory attendance: The forms of determining and announcing activities that require compulsory attendance in distance education programs are mentioned in this section.

e. Assessment and Evaluation: The criteria for conducting assessment and evaluation activities in distance education programs (face-to-face-electronic, supervised-unsupervised), methods (oral examination, performance, project, thesis, portfolio), and the effect ratio of activities on the overall success are determined under this heading.

f. Assignment of Academic Staff: Which institution will decide on the assignment of academic staff was stated in this section.

\section{Financial Provisions}

a. Tuition fees and material fees: The principles of determining material fees are mentioned under this heading.

b. Budgeting operations: The criteria for fees to be charged to students are mentioned in this section.

c. Additional course fees and other payments: The issues taken into consideration while calculating additional course fees in distance education, payment methods, and the upper limit determined for an additional course fee and additional course hour, and the maximum number of courses that a faculty member can take are stated in this section.

d. Examination fees: The criteria taken into consideration in the payment of examination fees are discussed and expressed in this section.

e. Authority: The authority for the sub-arrangements to be made by the boards of higher education institutions, provided that they are not contrary to the mentioned Procedures and Principles, is stated in this section.

\section{Miscellaneous and Final Provisions}

In this section, the date of the entry into force of the Procedures and Principles regarding Distance Education in Higher Education Institutions and executive authority are mentioned.

\section{Other Services}

In the final section of the Procedures and Principles regarding Distance Education in Higher Education Institutions, calculation criteria were established by adding scales related to the payments to be made in return for duties in the central examination and other services. It is observed that the Procedures and Principles regarding Distance Education in Higher Education Institutions cover areas in which distance education programs can be opened in higher education institutions, courses to be given through distance education and their credits, the preparation of course materials, the way of conducting examinations, protocols to be made for this purpose between higher education institutions, payments to be made, and other issues related to distance education.

All structural and functional issues related to distance education activities in higher education are regulated centrally by the Council of Higher Education (YOK) (Simsek, 2007). Therefore, the effect of central regulations on distance education is more significant as well as in all areas because all amendments and arrangements that are made centrally directly affect all parts of the system. These Procedures and Principles 
ensure standardization at the point of implementation and conducting activities for distance education centers and higher education institutions to which they are affiliated. By eliminating differences in application between distance education centers in different universities, the scope of applications has become clear, and a framework has been formed. Despite all these positive developments, it draws attention that the current amendments to the mentioned Procedures and Principles are not sufficient at the application dimension, and there are some expectations. Indeed, at a workshop organized by Anadolu University in 2015 and attended by open and distance education institutions, the presence of financial and legislative problems was mentioned. It was emphasized that the most important one of these problems was that the existing procedures and principles forced to follow a standard teaching strategy and did not support creative designs (HEC, 2015).

This study's goal is to reveal amendments to the Procedures and Principles regarding Distance Education, areas affected by these amendments, problems, and expectations. In line with the aim of the study, answers to the following questions were sought:

1. What are the amendments to the Procedures and Principles regarding Distance Education in Higher Education Institutions, and the areas affected by them?

2. What are the problems and expectations related to the Procedures and Principles regarding Distance Education in Higher Education Institutions?

a. What are the problems and expectations at the system level?

b. What are the problems and expectations at the program level?

c. What are the problems and expectations at the course level?

It is essential to reveal amendments to the Procedures and Principles and the current problems and expectations in terms of determining what the requirements for distance education activities are and what needs to be expressed more clearly. Nevertheless, central regulations on distance education (limitation, flexibility, or guidance) are very important since they reveal in detail the reflections of the system, program, course, and even in-class activities on the design process in distance education. Furthermore, the determination of how practitioners are affected by these regulations directly based on their experiences provides a holistic view on different levels of distance education. It is estimated that the results of this study will shed light on and guide the central regulations related to distance education.

\section{METHOD}

The qualitative research approach was adopted in the study. The aim of the qualitative research approach is to examine data in depth and to reveal relationships between data (Yildirim and Simsek, 2006). In this study, document review was used as a data collection method for the first research question. Document review is the analysis of written materials that contain information about the phenomena intended to be investigated (Yildirim and Simsek, 2006). To find an answer to the second research question, the interview data collection method was used, and a semi-structured interview form was created.

\section{Participants}

For the first research question, two published copies of the Procedures and Principles regarding Distance Education in Higher Education Institutions were used. For the second research question, eight people who had served for at least three years as administrators in distance education centers of universities in Turkey and who were selected by the criterion sampling method among purposive sampling methods were interviewed. The administrators of institutions providing distance education constituted the study group since they were individuals who had a grasp of the policies for distance education practices and were directly affected by these policies. Within the scope of this study, having served for at least three years was accepted as a criterion. The administration experience of the study group in distance education ranged from 3 to 8 years. The data collection process was terminated when it was realized that the data reached saturation with the statements of eight people. 
The duties performed by the participants within distance education centers, their terms of duty, and their ages are shown in Table 1.

Table 1. Information on the Study Group

\begin{tabular}{cccc}
\hline Participant No & Duty & Term of Duty (years) & Age \\
\hline P1 & Director & 4 & 41 \\
P2 & Deputy Director & 3 (Currently) & 40 \\
P3 & Director & 8 (Currently) & 38 \\
P4 & Director & 4 (Currently) & 42 \\
P5 & Director & 7 (Currently) & 34 \\
P6 & Deputy Director & 7 & 32 \\
P7 & Director & 4 & 34 \\
P8 & Director & 3 (Currently) & 34 \\
\hline
\end{tabular}

The participants in the study group ensured that a different number of programs at different levels were conducted through distance education within the distance education centers of their universities. Table 2 presents information on the programs conducted in the distance education centers of the study group.

Table 2. Program Information of the Study Group

\begin{tabular}{|c|c|c|}
\hline Participant No & Program Information & Number of Programs \\
\hline P1 & On-Campus Common Compulsory Courses & \\
\hline \multirow{3}{*}{ P2 } & Master's Degree & 1 \\
\hline & Associate Degree & 1 \\
\hline & On-Campus Common Compulsory Courses & \\
\hline \multirow{4}{*}{ P3 } & Master's Degree & 4 \\
\hline & Bachelor's Degree Completion & 1 \\
\hline & Associate Degree & 6 \\
\hline & On-Campus Common Compulsory Courses & \\
\hline P4 & On-Campus Common Compulsory Courses & \\
\hline \multirow{3}{*}{ P5 } & Certificate Program & 3 \\
\hline & Bachelor's Degree Completion & 1 \\
\hline & On-Campus Common Compulsory Courses & \\
\hline \multirow{3}{*}{ P6 } & Master's Degree & 6 \\
\hline & Bachelor's Degree Completion & 4 \\
\hline & On-Campus Common Compulsory Courses & \\
\hline \multirow{3}{*}{ P7 } & Master's Degree & 6 \\
\hline & Bachelor's Degree Completion & 4 \\
\hline & On-Campus Common Compulsory Courses & \\
\hline P8 & On-Campus Common Compulsory Courses & \\
\hline
\end{tabular}

As is seen in Table 2, on-campus common courses are conducted in all distance education centers where the study group participants work, and a different number of master's degree, bachelor's degree completion, and associate degree programs are carried out in some of them. There is also a certificate program in a distance education center where one participant works.

\section{Validity and Reliability}

Confirmations were received from the participants, and opinions were obtained from two different experts to ensure the validity and reliability of the study. Some resulting differences were discussed among the experts, and a decision was taken on final codes, categories, and themes. Cross-check was performed by two researchers to check whether the codes adequately reflected the issue examined. Some of the data were 
re-analyzed by the same researcher after approximately a year to ensure the reliability of the codes generated during the data analysis process. The internal consistency of the two coding processes was found to be .85 . This result can be regarded as a piece of evidence for the required level of reliability.

\section{Data Collection}

For the first research question in the study, two published copies of the Procedures and Principles regarding Distance Education in Higher Education Institutions were examined. A semi-structured interview form was created for the second research question. Experts in the field of education and evaluation were consulted for the final version of the questionnaire, and then the form was finalized.

\section{Data Analysis}

In this study designed according to the qualitative research approach, the data on the first research question were analyzed by document review. Document analysis is a method of analysis in which written materials (books, journals, newspapers, e-content documents) are examined (Miles and Huberman, 1994).

The data on the second research question in the study were analyzed by content analysis. Content analysis is bringing together similar data within the framework of certain concepts and themes and arranging and interpreting these data in a way that the reader can understand (Miles and Huberman, 1994). In this context, interviews conducted with the participants within the scope of this study were recorded by a voice recorder, and all data obtained were transcribed. The research results were obtained by analyzing the data of documents and interviews.

\section{FINDINGS}

In this study, it was tried to reveal amendments to the Procedures and Principles regarding Distance Education in Higher Education Institutions, practices affected by the amendments, and expectations at the system, program, and course levels in the Procedures and Principles regarding Distance Education in Higher Education Institutions. The results obtained in accordance with the research questions are presented below, respectively.

\section{Amendments to the Procedures and Principles regarding Distance Education in Higher Education Institutions and the affected areas}

After the Council of Higher Education issued the Procedures and Principles regarding Distance Education in Higher Education Institutions in 2013, amendments to the Procedures and Principles were made on 20.02.2014. Some of these amendments were as follows: making additions to the article content, reducing issues in the article content, and changing the article content. Along with these amendments, changes were also made in distance education practices. In Table 3, amendments to the Procedures and Principles regarding Distance Education in Higher Education Institutions are mentioned.

It is known that some amendments were made to the Procedures and Principles regarding Distance Education in Higher Education Institutions in 2014. It is understood that these amendments were mainly in the articles under the headings of program and course opening, branching, assignment, and student admission. It is also noteworthy that there are expression additions and the removal of expressions in some articles, and extensive changes in expressions in the others. In Table 3, the articles with addition, removal, and change in the Procedures and Principles regarding Distance Education in Higher Education Institutions, information on the change status, and the articles amended in the content of the article, the type of amendment, and the content of the amended article are clearly stated. 


\begin{tabular}{|c|c|c|c|c|c|c|c|c|c|c|c|c|c|c|}
\hline 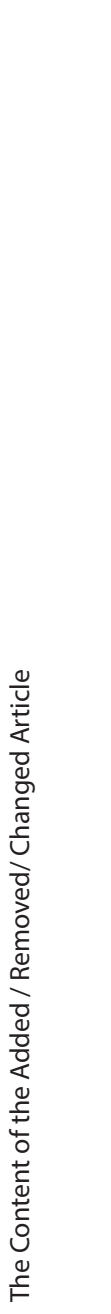 & 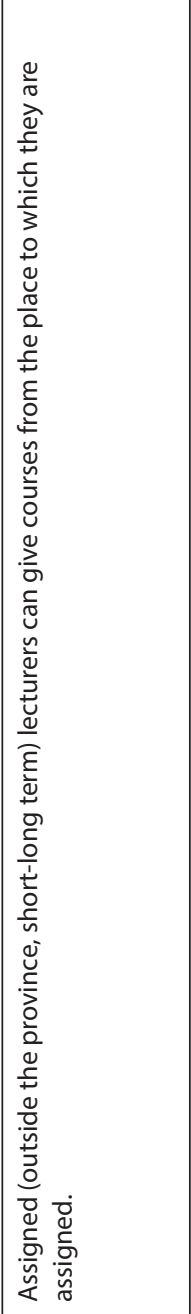 & 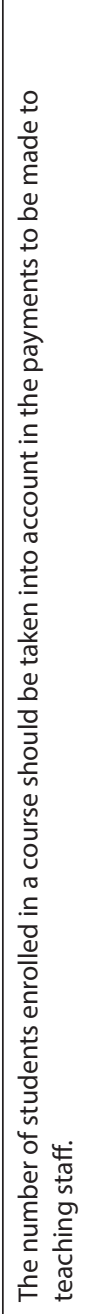 & 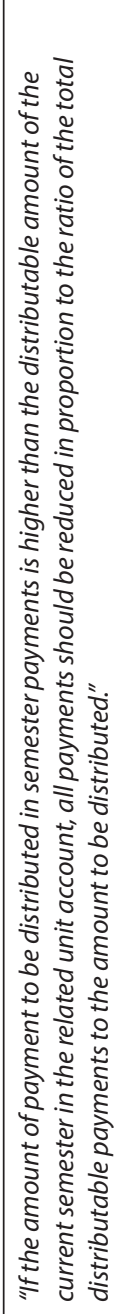 & & 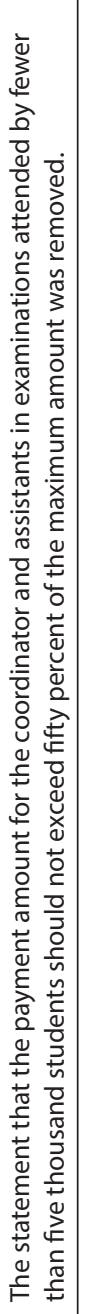 & 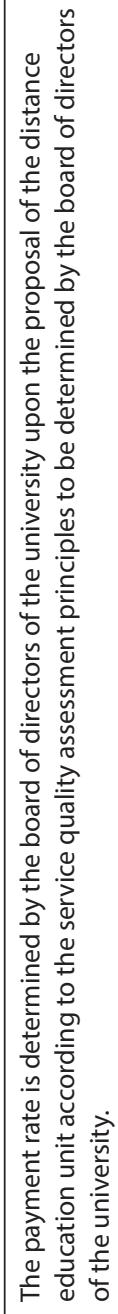 & 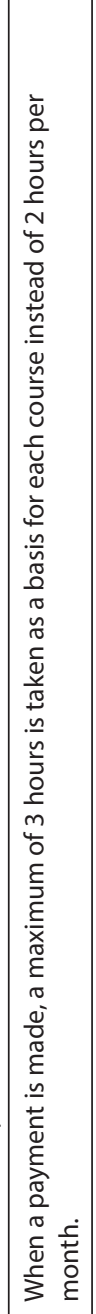 & 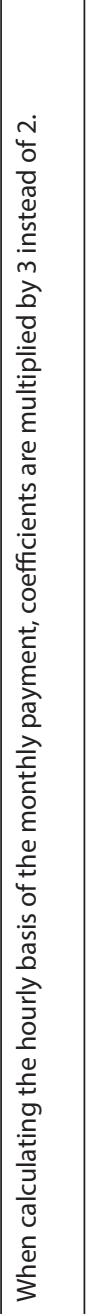 & 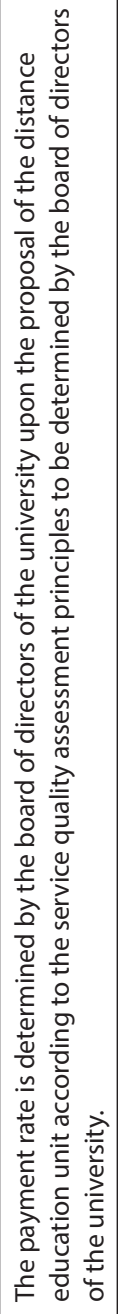 & 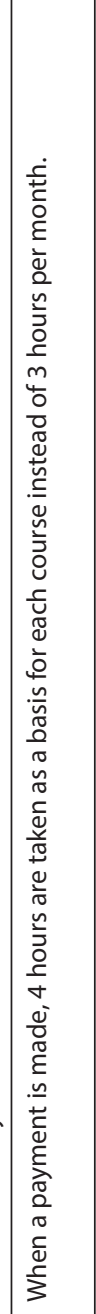 & 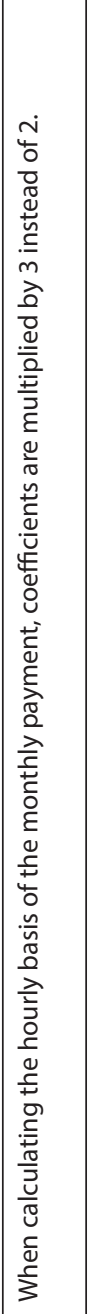 & & 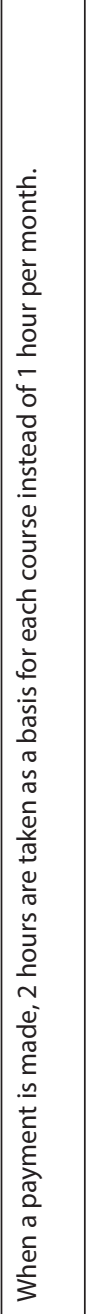 & 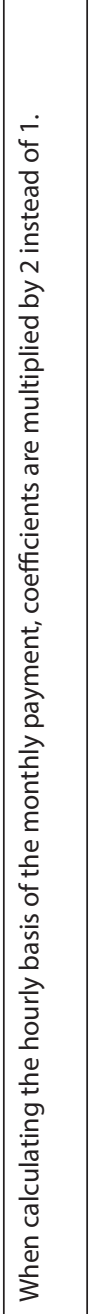 \\
\hline 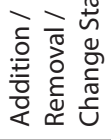 & 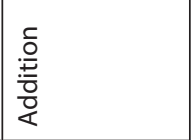 & 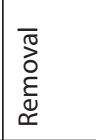 & 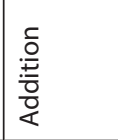 & & 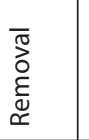 & 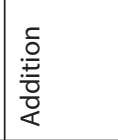 & 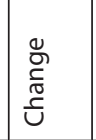 & 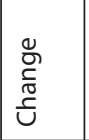 & 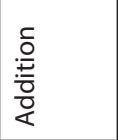 & 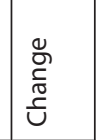 & 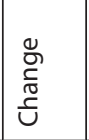 & & 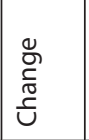 & 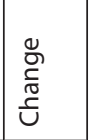 \\
\hline 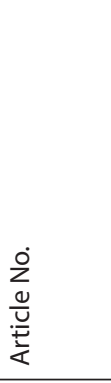 & 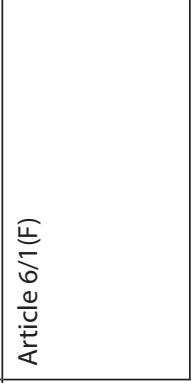 & 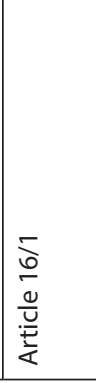 & & 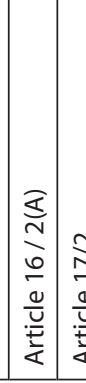 & 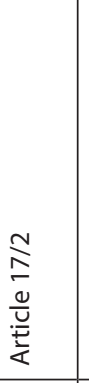 & 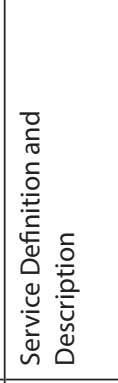 & 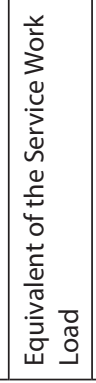 & 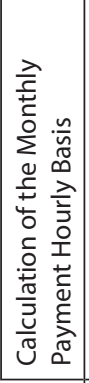 & 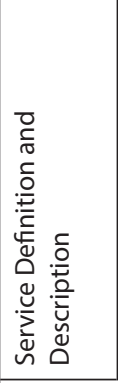 & 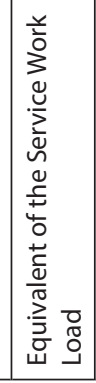 & 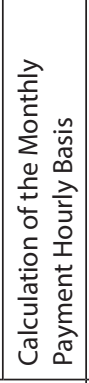 & 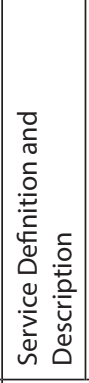 & 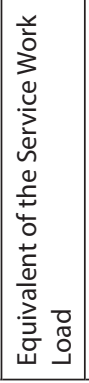 & 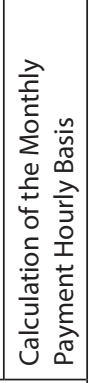 \\
\hline 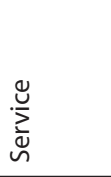 & & & & & & & 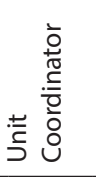 & & & 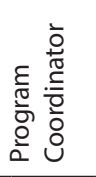 & & & 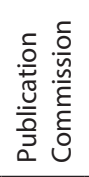 & \\
\hline 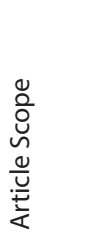 & 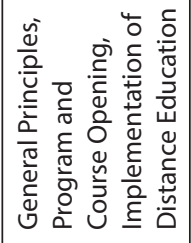 & & 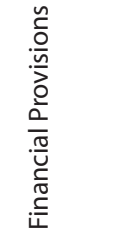 & & & & & & 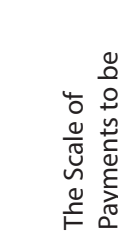 & 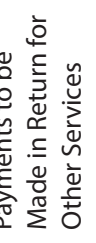 & & & & \\
\hline
\end{tabular}




\begin{tabular}{|c|c|c|c|c|c|c|c|c|c|c|c|c|c|c|c|c|c|}
\hline 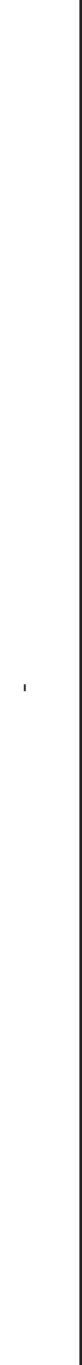 & 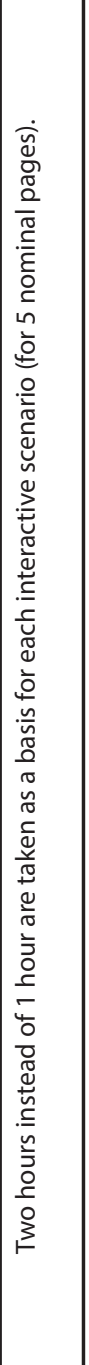 & 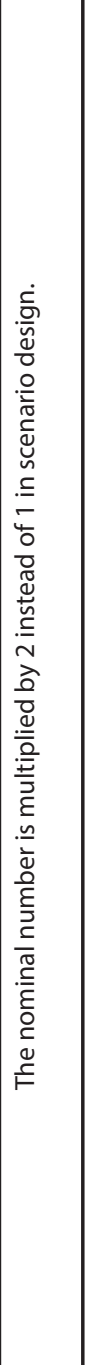 & & 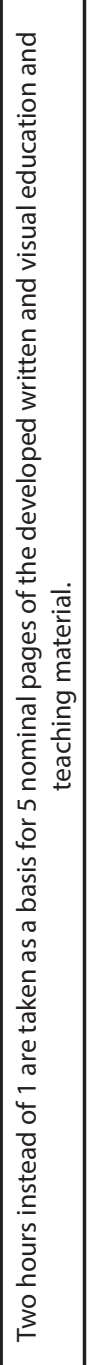 & 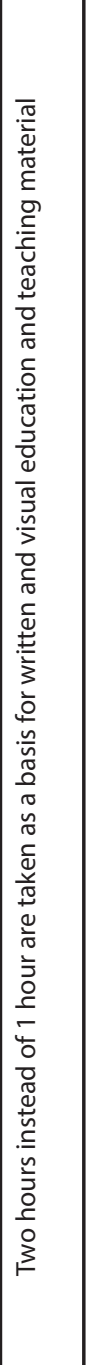 & & 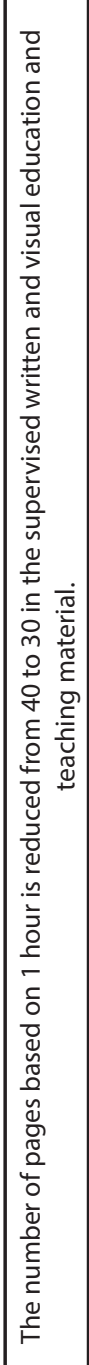 & 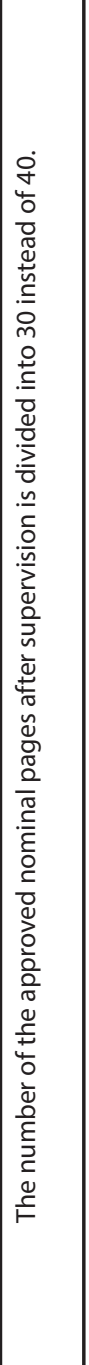 & 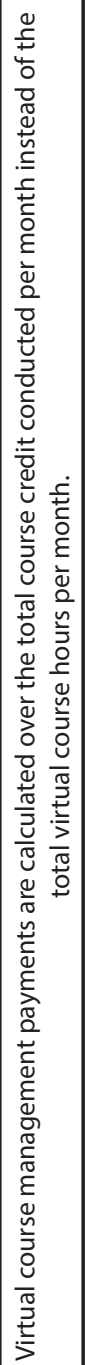 & 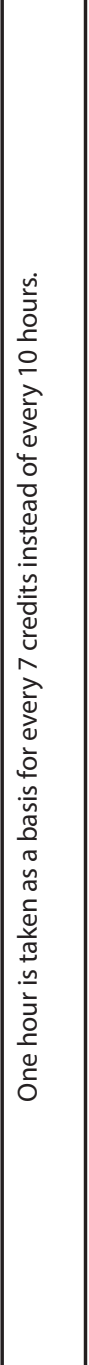 & 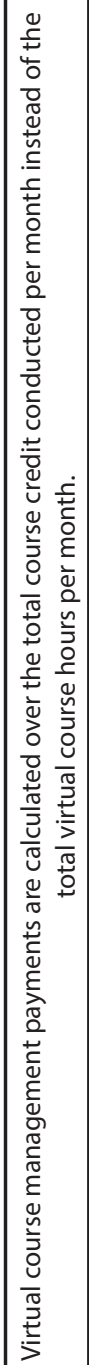 & 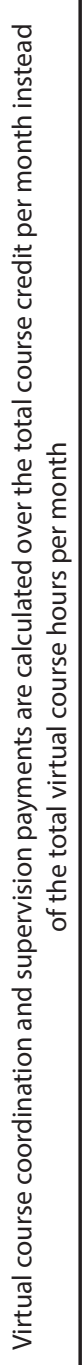 & 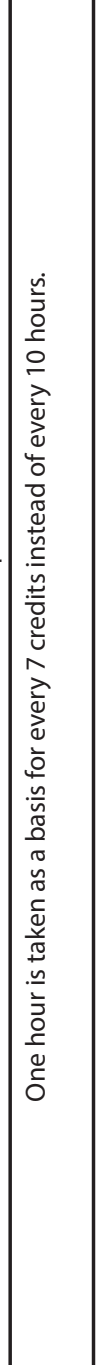 & 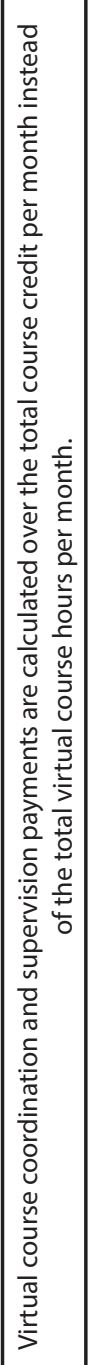 & & 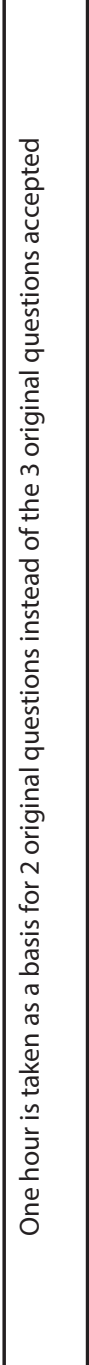 & 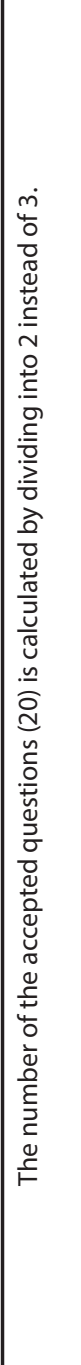 \\
\hline ' & 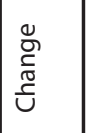 & 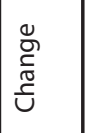 & & 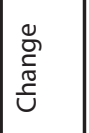 & 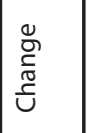 & & 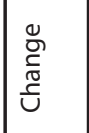 & 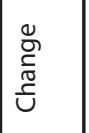 & 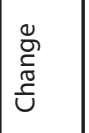 & 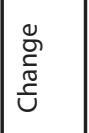 & 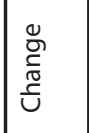 & $\begin{array}{l}\frac{}{\circ} \\
\frac{0}{7} \\
\frac{7}{0}\end{array}$ & 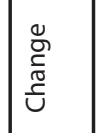 & 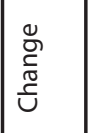 & 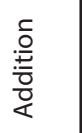 & 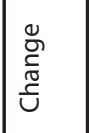 & 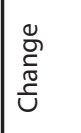 \\
\hline 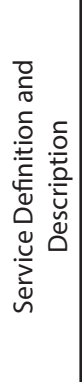 & 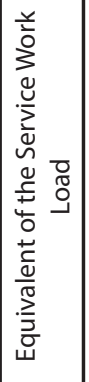 & 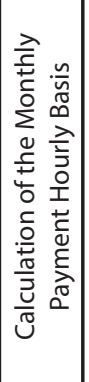 & 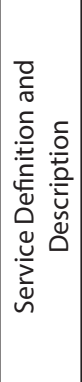 & 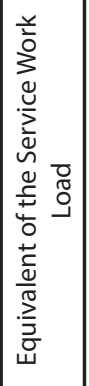 & 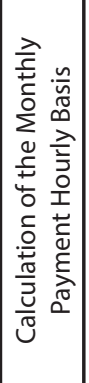 & 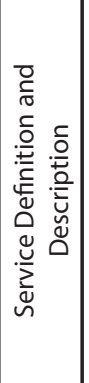 & 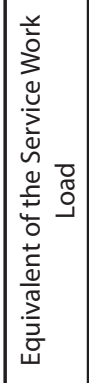 & 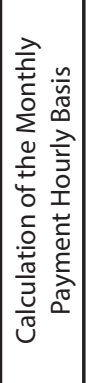 & 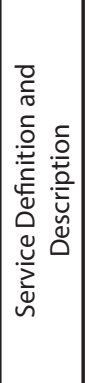 & 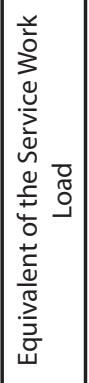 & 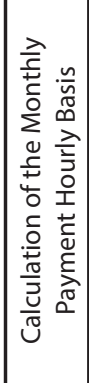 & 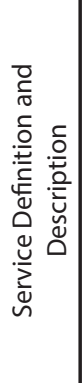 & 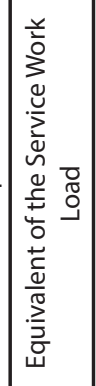 & 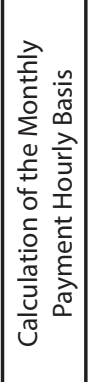 & 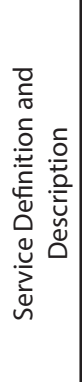 & 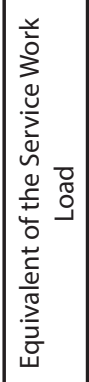 & 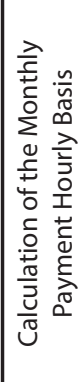 \\
\hline & 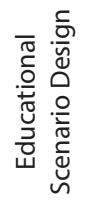 & & \multicolumn{3}{|c|}{ 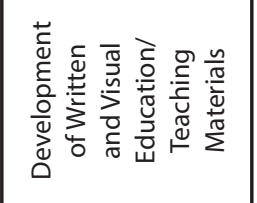 } & \multicolumn{3}{|c|}{ 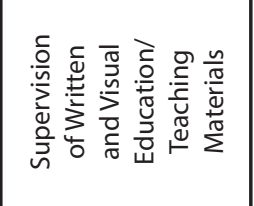 } & \multicolumn{3}{|c|}{ 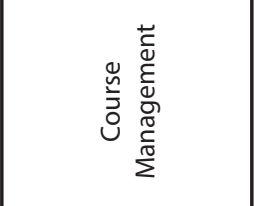 } & \multicolumn{3}{|c|}{ 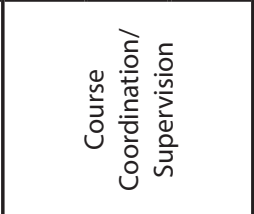 } & \multicolumn{3}{|c|}{ 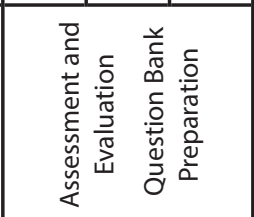 } \\
\hline \multicolumn{18}{|c|}{ 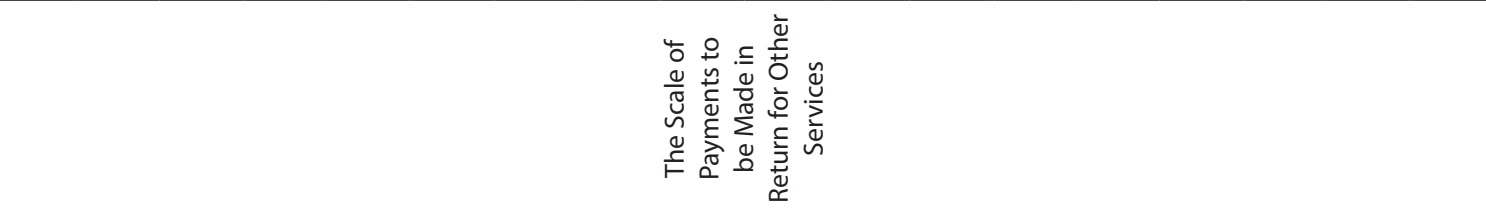 } \\
\hline
\end{tabular}


As a result of the analysis, it is observed that there are additions, removals, and complete changes in some articles of the Procedures and Principles regarding Distance Education in Higher Education Institutions. It is understood that amendments are related to the conduct of courses in assignments outside the province, the calculation of payments made to lecturers, issues in payments made to coordinators and their assistants, and change in the coefficient that is taken as a basis in the calculation of payments to persons assigned in distance education.

\section{Problems and Expectations for the Procedures and Principles Regarding Distance Education}

The procedures and principles regarding distance education have ensured the conduct of distance education practices on a basis. The existence of the procedures and principles has established certain standards, particularly in terms of system structuring and conducting programs and course activities. Analyses indicate that these standards have not been sufficient to fill in some gaps in distance education practices.

As a result of the studies conducted, it is observed that there are problems and expectations about the Procedures and Principles regarding Distance Education in Higher Education Institutions at the system, program, and course levels. Figure 2 presents problems and expectations for the Procedures and Principles, which were revealed as a result of the interviews conducted within the scope of the study.

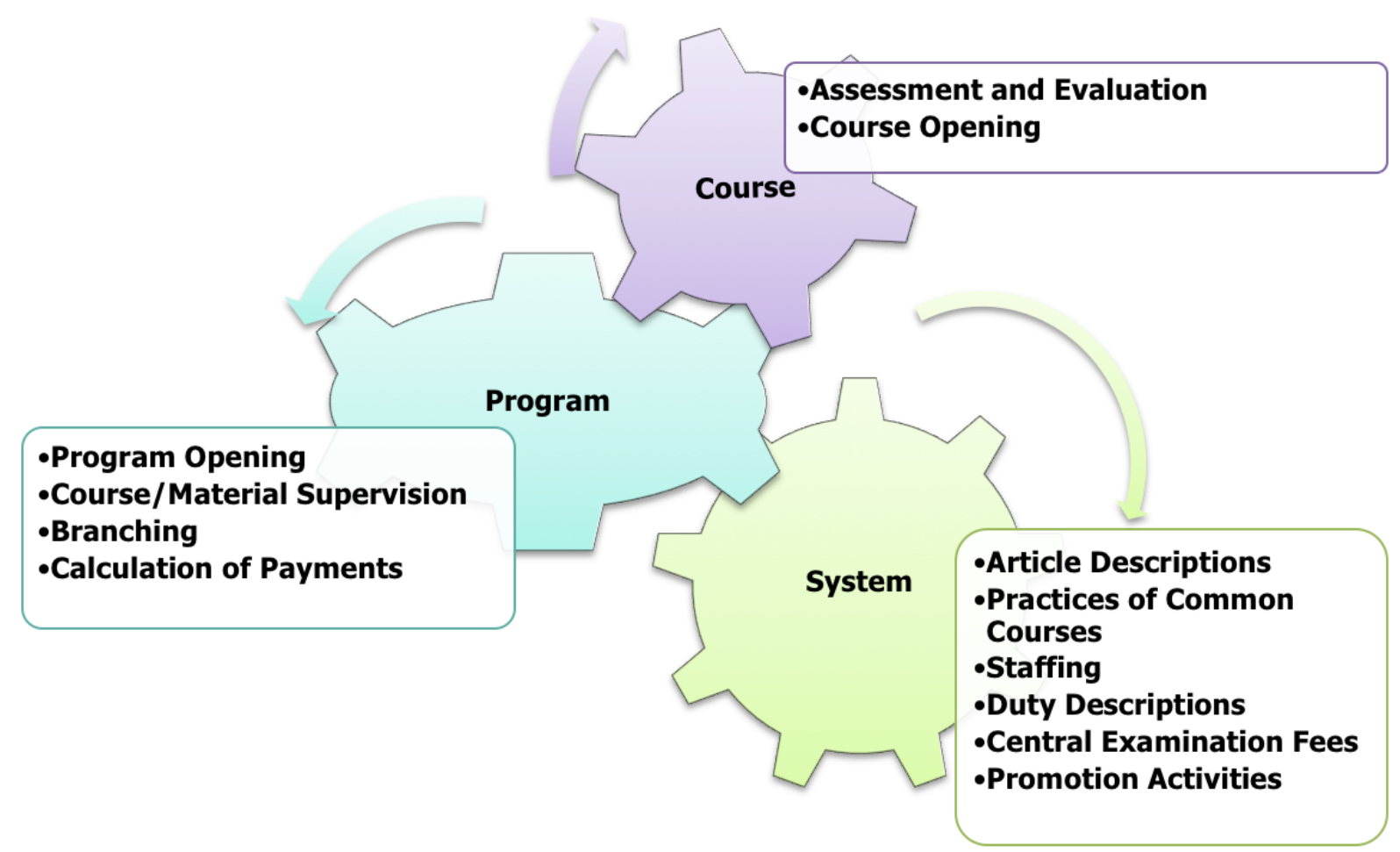

Figure 2. Problems and Expectations for the Procedures and Principles Regarding Distance Education in Higher Education Institutions

\section{Problems and Expectations at the System Level}

The interviews conducted within the scope of the study show that the presence of some points that should be developed at the system level is remarkable. These points are understood to be mainly expectations for explicit expressions and expectations for descriptive expressions of specific issues. Expectations are observed to be primarily for clarifying statements about staffing, central examination fees, and promoting and dissemination activities of distance education. 


\section{Expectations for Uncertainties in the Articles of the Procedures and Principles}

All distance education centers in Turkey carry out their practices according to the Procedures and Principles regarding Distance Education in Higher Education Institutions. Although the board of directors has taken decisions and established implementation principles in some special cases, differences experienced in implementation leave distance education centers in a problematic situation in terms of operation. Problems and expectations were stated for expressions in the articles of the Procedures and Principles regarding Distance Education in Higher Education Institutions to contain more explicit judgments and to be expressed in such a way that will not cause confusion. Statements of a few participants regarding this situation are presented below:

"Assessment and evaluation are mentioned, but it will be better if there is also clarity there, regarding what will be included in the evaluation. It's not certain. Teachers say, let's make a test and pass it. Everything should be explained in more detail." (P1)

"The duties and authorities of distance education centers and other units should obviously be expressed more clearly in the procedures and principles. There are implementation differences." (P2)

"Who should be in the publication commission, what they should do, what a supervisor will do should be stated more clearly." (P3)

"The procedures and principles are our source of defense. If there is a discussion, we rely on an article if it is open and clear, but it becomes uncertain what we will do on issues that are not included. The articles in the procedures and principles should be open and clearly stated." (P4)

"It is said "original," but what does it mean "original"? Will it be sufficient to add references? These should be certain." (PG)

"There is no clarity about opening a program. There must be clear statements regarding this. Limitations in opening a program, a department should be eliminated." (P7)

"It is not clear which items for distance education programs apply to common courses and which do not." (P8)

Considering the participant statements, it is observed that the fact that the articles in the procedures and principles contain ambiguous statements makes the functioning of distance education more difficult. In particular, there are problems and expectations for clarifying uncertainties experienced in terms of the duty and authority definitions, assessment and evaluation practices, and payments to be made to faculty members, and statements open to interpretation.

\section{Expectations for the Absence of Articles Specific to the Common Compulsory Courses Taught through Distance Education}

The common compulsory courses taught at universities to which distance education centers are affiliated are taught through distance education. However, it was determined that the articles in the current procedures and principles do not cover some common compulsory courses. The lack of articles specific to common compulsory courses in the procedures and principles was stated by the participants as a severe problem for distance education centers, especially conducting only common compulsory courses. There is a need for articles supported by clear statements, especially on issues of virtual courses, exam preparations, content development, and payments to be made to lecturers and examiners. Statements of a few participants regarding this situation are as follows:

"Distance education first starts with common courses. Teachers can't keep up. Classrooms are not enough. They say, let's teach it through distance education, but it is not clear in the regulation according to which we will make a payment, and some distance education centers take the initiative. We could not pay teachers when we taught virtual courses." (P4) 
"We could not pay teachers when we gave live lessons for common courses.

The motivation of teachers was also decreasing. We could not manage the system." (P6)

"Central examination is held in exams of common courses. However, officers are not paid. There were those who asked why they were not paid." (P7)

"There are no special articles for common courses. Teachers who teach common courses experience problems in getting a payment, they demand payment, but they cannot be paid according to the legislation. Even those who take part in the central examination of common courses demand payment, but they cannot be paid." (P8)

When the participant statements are examined, it is observed that there is a need for articles about virtual classes of common courses, exam preparations, content development, and payments to be made to lecturers and examiners in the procedures and principles.

\section{Expectations for the Lack of Staffing Authority}

Distance education centers, which have the status of other research centers under the current conditions, face some difficulties while undertaking this role. Although distance education centers are institutions that provide support to faculties and institutes in the conduct of virtual classes, the creation, development, and uploading of course materials into the system, and conducting assessment and evaluation activities, they do not have their staffing mechanism. While carrying out their duties, distance education centers employ staff from other departments. In the case of the insufficiency of personnel, there may be disruptions and problems in the specified working processes. The statements of a few participants concerning this situation are presented below:

"All our staff members work as employees from other departments. We may have to do a lot of work with very few people."(P5)

"There is no technical staff working permanently with us since the staff in centers is assigned. We are doing this job even with deputy directors. For example, our staff normally work in the Computer Sciences Research and Application Center. We call them when there is a job." (P6)

"We demand personnel recruitment. The center has no authority to recruit personnel. You need personnel concerning this, but you cannot put an advertisement."(P7)

"Non-expert people are assigned to the unit so that they would learn the work, and they are overloaded."(P8)

When the statements of the participants are examined, the lack of the staffing authority of distance education centers manifests itself as an inadequacy, especially in the increase in workload and specialization of the staff.

\section{Expectations for not Clear Duty Descriptions}

Distance education centers carry out their practices in cooperation with faculties/institutes/vocational high schools at universities to which they are affiliated. This cooperation is provided, especially at the stages of the effective conduct of virtual classes, the development of course contents, and conducting exams. However, the unclear distribution of tasks in the joint working stage also leads to problems in cooperation. The participant statements concerning this situation are as follows:

"It is not clear what distance education will do and who will do what job. It will be very good if these are defined in the procedures and principles." (P3)

"We take on everything while conducting programs. However, this time, we are unable to solve the problems." (P8) 
The distance education staff coordinates the teaching and examination of bachelor's degree completion and postgraduate programs carried out by distance education, as well as tasks related to common compulsory courses in vocational high schools and faculties in the districts at Ataturk University. Lecturers are supported in the teaching activities of courses, while assessment and evaluation activities are conducted entirely by distance education centers. This causes the workload of the personnel at distance education centers to exceed the reasonable limits. Despite these situations, the preparation of common course examinations is not included in the scope of payments in central examinations. Statements of a few participants concerning this situation are presented below:

"Central examination is held in exams of common courses. However, officers are not paid. There were those who asked why they were not paid." (P1)

"The procedures and principles do not cover common courses. There is a need for updating. We are making exam preparations, but we cannot pay a penny." (P2)

"We don't make payments in common courses, anyway." (P3)

"We held the central examination of common courses. However, we could not pay. It is usual for them. Consequently, the expectation emerges.” (P8)

It is observed that the scale of payments given in Appendix-1 of the Procedures and Principles is not taken into consideration in the payment of examination fees of common courses carried out within distance education centers. It is stated that this situation constitutes a problem for the distance education center personnel who spend overtime for this.

\section{Expectations for the Low Perception of Distance Education}

The instructor of a course taught through distance education provides the content of the course and exam questions or conducts virtual classes. In the Procedures and Principles regarding Distance Education in Higher Institutions, criteria that will change the perceptions of faculty members of distance education or will provide the widespread of distance education are not mentioned. Although there is guidance, there are also shortcomings. The statements of a few participants concerning this situation are presented below:

"There are teachers who are not very willing to conduct a distance education course. We are trying to encourage them by our own means, to the extent it is sufficient ... " (P1)

"The procedures and principles should pave the way for initiatives to change the perception of distance education." (P3)

"Lecturers do not adopt distance education. We tried to convince teachers. We gave a seminar. Can't something be done with this?" (P5)

"The motivation of teachers towards distance education is really low ..." (P8)

When the participant statements are taken into consideration, it is observed that the transition of faculty members to distance education is not at the desired level. There is a need for mechanisms that will support the skills of faculty members necessary for distance education.

\section{Problems and Expectations at the Program Level}

Problems and expectations in the program dimension are observed to be concentrated in the fields of program opening, content supervision, and determining supervisors, branching, and payment calculations. 


\section{Expectations for Difficulties Aat the Stage of Program Opening}

There are some requirements for opening a program that is planned to be conducted through distance education. When a request is made to the Council of Higher Education for a program to be taught through distance education, information should be provided about the technical infrastructure facilities of a distance education center, the number of staff, and the equipment to be used during the execution of the program. However, some difficulties are experienced at this point. If there is a lack of technical infrastructure and staff within the center, the Council of Higher Education does not approve of opening a program. However, the university rectorate has an approach that the technical infrastructure and personnel support will be provided in case of opening new programs. The statements of a few participants regarding this situation are as follows:

"The Council of Higher Education does not accept all content when you want to open a program. SCORM says it should be compatible, interactive. However, at the moment, we cannot get staff to ensure these in a technical sense. The existing ones work in other units." (P5)

"Even though we make a request to the Council of Higher Education for opening a program, the lack of personnel comes to the fore. The rectorate says that the department should be opened so that it can provide the staff. The Council of Higher Education says that you cannot open a department without interactive, SCORM-based content, and technical infrastructure. Since we have few people now, we cannot open a new program." (PG)

When the participant statements are examined, it is understood that there are procedural barriers that distance education centers experience in program opening. Furthermore, distance education centers, which carry out their studies with limited opportunities and very few personnel, have difficulties in overcoming this situation.

\section{Expectations for the Control of Course Contents}

For each course taught through distance education, different types (presentations, visual materials, textbased materials, etc.) of course materials are prepared by faculty members who will teach the course. These prepared materials are examined by supervisors in terms of their compliance with copyright and the methods of preparation of teaching material in the Procedures and Principles. The interviews demonstrated that there were problems at the point of supervising and reporting of course materials by supervisors. Moreover, it was stated that calculating and pricing the number of nominal pages of materials was a very time-consuming and complex process. The statements of a few participants concerning this situation are presented below:

"The roles of the supervisor are stuck in the air in that respect." (P4)

"Supervisors only count pages, and the item is also not clear. How visuals, tables, and graphs in reading texts would be calculated?" (PG)

"We cannot go beyond calculating the number of pages because supervisors do not have a command of everything." (P7)

When the statements of the participants are examined, it is observed that supervisors who control course materials experience some problems while performing their duties. These problems are mainly caused by the failure to specify the supervision criteria in an open and clear way. At the same time, it is understood that supervisors perform formal control rather than content control when examining materials of a course in which they are not domain experts.

\section{Expectations for Branching}

One of the remarkable practices related to central regulations is the branching and the limitation of branch quotas. Program branching and branch quotas in paragraph 1 of article 7 of the procedures and principles are specified in fixed numbers. However, not using explicit expressions throughout the article makes the application more difficult. The analysis of the statements of administrators about their experiences indicated that they did not provide sufficient guidance on branching, they were unable to act flexibly due to a scaring 
limitation, they could not decide on how to reflect this situation to different distance education practices such as common compulsory courses, and they had difficulties in it. Statements of a few participants regarding this situation are as follows:

"We cannot decide whether to open a branch for ten people or add them to another branch." (P1)

"When we open a new branch, it is necessary to assign a teacher to that branch. However, a teacher cannot attend classes in more than two branches at the same time. We think where to place a small number of students." (P2)

"Difficulties are inevitably experienced in branching. For example, 150 people are assigned to each branch in an undergraduate program. If the number exceeds 150 people, a second branch is opened. If 630 people take the course, a new branch should be opened, and new teachers should be assigned for 30 people. Sometimes, there is no teacher in the department. Can't be these numbers made more flexible?"(P7)

"There is no statement regarding how many people can be in a branch of a course for common courses." (P8)

In general, there are problems due to the lack of clear items related to branching. The branch quotas specified by exact numbers are observed to bring about some problems in case of the presence of more than one branch. Especially when a new branch needs to be opened since the branch quota is filled, there appears to be a need for guidance on how to apply quotas, which seems to cause severe instability and burden on practitioners. Furthermore, different interpretations of distance education administrators for branching on a personal basis prevent the formation of standard practices expected by the central regulation. Nevertheless, the fact that branching practices are directly related to pricing makes administrators feel more stressed.

\section{Expectations for Payment Calculations}

In distance education, the unit student coefficient is included in calculations when a payment is made to a unit coordinator, the program student coefficient is included in calculations when a payment is made to a program coordinator, and the course student coefficient is included in calculations when a payment is made to a lecturer teaching the course. The unit student coefficient refers to a number found by dividing the current number of students by the opened quota to be taken as a basis for calculating payments to be made to unit coordinators assigned in distance education diploma programs opened in the relevant units continuing education. The program student coefficient is a number found by dividing the current number of students by the opened quota to be taken as a basis in calculating payments to be made to program coordinators assigned in distance education diploma programs. The course student coefficient refers to a number found by dividing the number of students enrolled in the course by the opened quota to be taken as a basis for calculating payments to be made to lecturers in courses given through distance education, except courses that are decided by the Senate to be given only through distance education. When the quota is not filled to full capacity, i.e. when there is no student enrollment at the quota rate opened for a program, there is a decrease in payments. However, for each course opened, planning is done, and courses are conducted without considering the number of students. The statements of a few participants regarding this situation are presented below:

"When the quota is not filled for all departments in distance education (when the course student coefficient decreases), the payment made to teachers decreases. Now, teachers prepare the lesson, but when the payment is so low, how efficiently they can spend a 3-hour class." (P1)

"When an equal payment is made to everyone according to the course student coefficient, departments with few students are not able to pay with their incomes. Therefore, they become unable to pay." (P2)

"Due to the course student coefficient, some teachers in distance education received the payment even lower than the daytime wage. There is obviously a problem in the course student coefficient." (P5)

"There is an unjust treatment concerning pricing for common courses ..." (P8) 
When the participant statements are examined, it is observed that faculty members who make all the preparations for a course and conduct the course suffer financially when the course student coefficient is taken into consideration in payments. It is also stated that this situation may cause reluctance to conduct a distance course among faculty members in the long term.

\section{Problems and Expectations at the Course Level}

There are also problems and expectations for the development of the procedures and principles at the course level. In the analysis, it is understood that these problems and expectations are related to assessment and evaluation activities and course opening procedures.

\section{Expectations for the Failure to Make Payments for Alternative Assessment and Evaluation Activities}

Payments for examinations conducted through distance education are mentioned in the Procedures and Principles. The environment (face-to-face-online) and observation (supervised-unsupervised) statuses are taken into account in examination payments. However, there are no statements regarding the scope, type, and pricing of alternative assessment and evaluation activities. The statements of a few participants regarding this situation are as follows:

"Although we want to support courses with different activities, unfortunately, it becomes a dream." (P1)

"We want some different types of questions (open-ended questions, assignments, etc.) to be asked in exams. However, teachers ask how they will be paid for this. We can't answer this. It just stays as it is." (P5)

"Multiple-choice questions are asked in exams. It is easier for teachers to prepare them. It is timeconsuming to give and evaluate assignments. It is said that the time spent is taken as a basis in the Procedures and Principles, but nobody knows how much the hourly rate will be." (P6)

When the participant statements are examined, it is observed that there is uncertainty about the time spent on alternative assessment and evaluation activities in distance education or how the actual contribution will be charged.

\section{Activities for Course Opening}

In the current situation, boards of higher education institutions can decide on faculty members who will give courses through distance education. However, faculty members cannot request to open a course. Therefore, there is a need for specifying the criteria for opening a distance course and application conditions for a faculty member who wants to conduct a distance course in the Procedures and Principles regarding Distance Education in Higher Education Institutions. If a faculty member wants to teach a course taught face-toface through distance education, there is a need for informing about this. Statements of a few participants regarding this situation are presented below:

"For example, a teacher wants to know what he will do, what article he will adhere to when he wants to teach a postgraduate course distantly." (PG)

"There are teachers who want to conduct a course through distance education. However, we don't know which path to follow on this subject." (P7)

There is obviously a need for a road map in the Procedures and Principles on this subject for faculty members who want to conduct a course through distance education.

As a result, there are periodic amendments to the legislation developed for distance education practices. However, these legislative amendments do not meet the expectations of practitioners at some points. In 
addition to the points that need to be developed, especially at the system level, a need for some improvements in program applications and course execution procedures draws attention. At the system level, mainly problems and expectations for the elimination of uncertainties in article definitions, special expressions for common courses, staffing authority, exam payments, and promotion activities come to the forefront. At the program level, there are problems and expectations for opening new programs, course/material supervision, branching, and payment calculations. At the course level, there are expectations for the mechanisms that encourage alternative assessment and evaluation activities and the criteria for course opening.

\section{DISCUSSION AND CONCLUSION}

The Procedures and Principles regarding Distance Education in Higher Education Institutions entered into force in February 2013 for the first time, and some amendments were made to them afterward. The preparation of the Procedures and Principles has become an essential step for the implementation of distance education in higher education institutions in Turkey. This study's goal is to reveal amendments to the Procedures and Principles regarding Distance Education, areas affected by these amendments, and to reveal problems and expectations. It is observed that there are periodic amendments to the legislation developed for distance education practices.

However, these legislative amendments do not meet the expectations of practitioners at a number of points. While it is desired to have qualified education with certain standards in distance education, limitations arising from political regulations cause administrators to take fewer risks as a result of having difficulty in decision-making, which causes the failure to open certain programs at all and the inability to conduct certain programs at the desired level so that new steps that can reveal the potential of distance education cannot be taken. Therefore, some expectations of distance education practitioners for distance education legislation appear. In addition to the points that need to be developed, especially at the system level, the need for some improvements in program applications and course execution procedures draws attention.

Within the scope of the study, expectations, especially for the elimination of uncertainties in article definitions, special expressions of common courses, staffing authority, examination payments, and promotion activities, come to the forefront at the system level. In addition to faculty members, administrative staff, teaching staff (research assistants, specialists, lecturers, teaching assistants) are also involved in distance education. In the study, the necessity of arrangements in assignment procedures performed to conduct distance education was stated. Gurer, Tekinarslan, and Yavuzalp (2016) emphasize that regulations on distance education practices should be legally clear. While carrying out their duties, distance education centers employ staff from other departments. In the case of the insufficiency of personnel, there may be disruptions and problems in the specified working processes. Dogan (2014) emphasizes that research assistants working in distance education centers related to the assignment from academic units feel psychological pressure and are not efficient.

$\mathrm{Li}$, Zhang, Yu, and Chen (2014) also emphasized the importance of establishing legal duties and responsibilities in distance education institutions. It was especially noted that administrative staff, teaching staff, and other assigned employees who support faculty members and bear the significant burden of distance education do not receive compensation for their labor both financially and morally. It was also stated that there is a need for a duty description in which a person assigned to coordinating the technical design and execution of a program will be named the "administrative and technical coordinator." Cho and Berge (2002) argue that sufficient rewards and incentives should be given to everyone working for a distance education program. Furthermore, it is suggested that a detailed guide should be prepared for employees, and their opinions should be obtained on determining the additional working hours to normal working periods. Isman (2011) emphasizes that distance education institutions must be open to innovation and change to be successful. Otherwise, organizational problems will inevitably emerge, and the program will turn into a slow and challenging process.

At the program level, there are expectations for opening new programs, course/material supervision, branching, and payment calculations. It was also stated that calculating and pricing the number of nominal pages of materials was a very time-consuming and complex process. It was emphasized that although lecturers prepare for a course regardless of the number of students taking the course, the fact that the course student coefficient is taken into account in calculating course payments causes discomfort among lecturers. 
Determining payment policies for the distance education activities of faculty members of institutions has become one of the most important problems. Payment policies may have significant effects on the essential points of the learning and teaching process, such as which materials will be used in a course and how active students will be. Moore \& Kearsley (2012) state that it can be regarded as part of the work of full-time faculty members, and in some applications, this is more valuable than efforts made for face-to-face students' classes and that additional payment mechanisms can be developed for this. Moore \& Kearsley (2012) indicate that developing course materials or designing and conducting a distance education course by faculty members are evaluated in this sense within rewarding mechanisms such as promotion in the position, etc.

At the course level, there are expectations for mechanisms that encourage alternative assessment and evaluation activities and criteria for course opening. Steps should be taken to remove barriers to distance education centers. It is understood that there are procedural barriers that distance education centers experience in program opening. Ozarslan and Ozan (2014) argue that criteria for opening programs in distance education should support flexible models, creativity, innovation, and diversity. Furthermore, course materials of different types (presentation, figure, text, etc.) are prepared by faculty members who will teach courses. These prepared materials are examined by supervisors in terms of their compliance with copyright and the methods of preparing teaching materials in the Procedures and Principles regarding Distance Education. The interviews demonstrated that supervisors experienced some difficulties in supervising and reporting course materials. The determination of supervisors, especially by ignoring the title and subject area expertise, constitutes a problem for healthy supervision.

\section{SUGGESTIONS}

The worldwide spread of distance education also increases the importance of distance education policies that appeal to the aim and care about quality. It is necessary to carefully focus on quality assurance with a holistic view by considering all factors affecting distance education to reach broader masses and provide them with effective learning opportunities. Distance education institutions, policymakers, and society should set comparable quality standards and external evaluation mechanisms for distance education in collaboration with a holistic view. Sound strategic planning is necessary to establish a sound technological infrastructure for distance education, to ensure the competence of students and instructors, and to encourage the design and development of qualified teaching activities and materials. The policies designed and implemented should also be examined by administrators of distance education institutions or policymakers after the policy development process (Lin, 2008).

In this study, there are some concrete suggestions for the relevant plans. They are listed below as follows:

- Distance education centers can be transformed into a different structure with its own personnel and assignment.

- The job descriptions of the administrative staff supporting the teaching staff and other assigned staff can be determined with clear statements.

- The mechanisms to encourage the execution of face-to-face courses through distance education can be supported by legislation. For example, distance teaching may contribute in the encouragement and promotion stages.

- Contribution can be made to the pedagogical and androgogical development of faculty members.

- Arrangements can be made in which unit, program, and course student coefficients are not included in payment calculations.

- A new method of preparing nominal pages can be created by classifying materials at the stage of material supervision and payment of copyrights.

- Asynchronous educational activities can be encouraged in distance education. Activities such as answering to students' questions, evaluating assignments, or practices that are available in the current form of the Procedures and Principles regarding Distance Education but that do not have an equivalent in the scale in Appendix-1 can be supported.

- Course credits can be taken into account in the payments of virtual courses. 
- In student branching, intervals can be determined instead of net numbers.

- A flexible system, in which new branches can be opened as the number of students participating in virtual courses increases, can be established.

Authors' Note: This study was presented as a summary paper at the $3^{\text {rd }}$ International Instructional Technologies and Teacher Education Symposium.

\section{BIODATA and CONTACT ADDRESSES of AUTHORS}

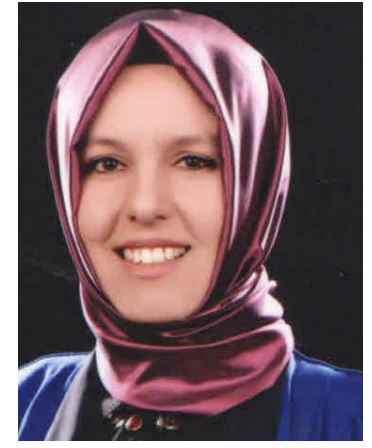

Dr. Munevver GUNDUZ is currently working at Ataturk University Teaching and Learning Development Application and Research Center as an Assistant director since February 2019. She is also doing her PhD at Computer Education and Instructional Technologies Department in Ataturk University. Her research interests include open and distance learning, dropout factors for open and distance learners. She worked at Ataturk University Distance Education Application and Research Center as a program coordinator between 2011 and 2019. She has several journal articles published on distance education and participated 10 national and international meetings in which her papers were submitted.

Munevver GUNDUZ

Teaching and Learning Development Application and Research Center, Ataturk University

Address: Ataturk University,25240, Erzurum TURKEY

Phone: +90 442 2315901,

E-mail: munevveresgice@gmail.com; mesgice@atauni.edu.tr

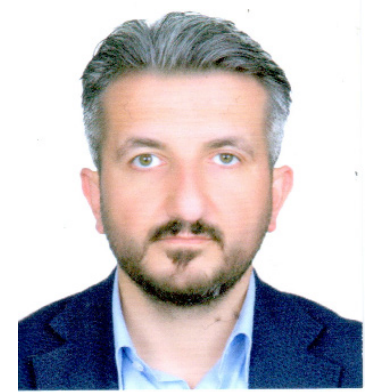

Dr. Engin KURSUN is an Assoc. Prof of Open and Distance Learning at Kazim Karabekir Education Faculty, Ataturk University. Dr. Kursun gained his PhD in Educational Technology at Middle East Technical University on September, 2011. His academic interest areas are open and distance learning, open educational resources, safer internet for children and human computer interaction. Dr. Kursun has authored over than 120 publications. He supervised $4 \mathrm{PhD}$. and 5 master theses. He has also contributed over than 20 national and international research projects.

\section{Engin KURSUN}

Department of Computer Education and Instructional Technology, Kazim Karabekir Education Faculty Address: Ataturk University,25240, Erzurum TURKEY,

Phone: +90 4422311416

E-mail: ekursun@atauni.edu.tr 


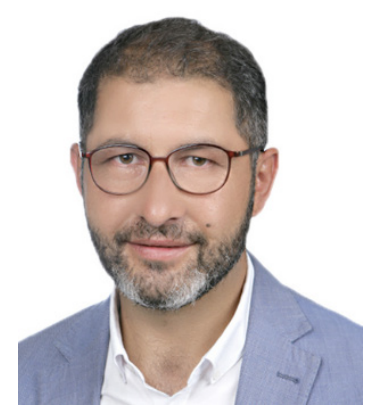

Dr. Selcuk KARAMAN is a Professor of Computer Education and Instructional Technologies Department at Kazim Karabekir Education Faculty, Ataturk University. Dr. Karaman completed his $\mathrm{PhD}$ on the topic of Learning objects management and design. His academic interest areas are digital transformation, open and distance learning, e-learning and performance technologies. He has many journal articles, book chapters and papers submitted to international meetings. He supervised $8 \mathrm{PhD}$ and 14 master theses.

\section{Selcuk KARAMAN}

Department of Computer Education and Instructional Technology, Kazim Karabekir Education Faculty Address: Ataturk University,25240, Erzurum TURKEY,

Phone: +90 4422315551

E-mail: skaraman@atauni.edu.tr

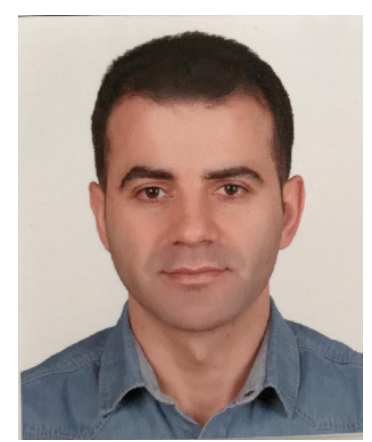

Dr. Turgay DEMIREL is currently working as an Assistant Professor of Computer Engineering Department at Igdir University since March 2018. He gained his $\mathrm{PhD}$ degree at Computer Education and Instructional Technologies Department in Ataturk University in January 2016. He is currently the head of Distance Education Research and Application Center of Igdir University since April 2018. His research interests are using web 2.0 tools in education, educational blogs, instructional technology integration, effective ICT usage, ICT perceptions, ICT competency, use of eye tracking in reading comprehension, reasons for manuscript rejection, game-based learning, mind games, open and distance learning, adaptation of distance education instructors, distance education policies. He has several journal articles published in SSCI and he participated over 20 national and international meetings in which his papers were submitted.

\section{Turgay DEMIREL}

Department of Computer Engineering, Faculty of Engineering

Address: Igdir University, 76000, Igdir, Turkey

Phone: $+904762230010 / 7913$

E-mail: turgaydemirel85@gmail.com; turgay.demirel@igdir.edu.tr

\section{REFERENCES}

Akan, H. (2012). Yuksekogretimde Reform mu, Onarim mi? [Reform or Repair in Higher Education?], Journal of Higher Education and Science, 2 , 24-25

Aydin, C. H. (2008). Uzaktan egitim sureclerinin tasarimi [Design of distance education processes]. Uluslararasi uzaktan egitim Konferansi, Maltepe Universitesi, 17-18 Ekim 2008: Istanbul. Retrieved December 11, 2015 from http://basin.maltepe.edu.tr/node/20

Darab, B., \& Montazer, G. A. (2011). An eclectic model for assessing e-learning readiness in the Iranian universities. Computers \& Education, 56, 900-910.

Cho, S. K., \& Berge, Z. L. (2002). Overcoming barriers to distance training and education. USDLA Journal, $16(1), 16-34$.

Dogan, H. G. B. (2014). Yuksekogretim kurumlarinda web tabanli uzaktan egitim programlari bilesenleri: Uygulamalar ve sorun alanlari [Web-based distance education program components in higher education institutes: Practices and problem areas]. Yayimlanmamis Doktora Tezi (Unpublisted Dissertation]. Hacettepe Universitesi Egitim Bilimleri Enstitusu, Ankara.

Gonzalez, A., \& Roig, H. (2018). Regulations for distance education for the Argentine university: Pending advances and challenges. Virtualidad Educacion Y Ciencia, 9(16), 152-157. 
Gurer, M. D., Tekinarslan, E., \& Yavuzalp, N. (2016). Cevrimici ders veren ogretim elemanlarinin uzaktan egitim hakkindaki gorusleri [Online instructors' views on distance education]. Turkish Online Journal of Qualitative Inquiry, 7(1).

Higher Education Council. (2015). Yuksekogretim Kalite Kurulu Bilgi Notu [Higher Education Quality Council: Annotation].

Kim, S., \& Kim, H. (2017). South Korea. In International perspectives on psychotherapy (pp. 139-157). Springer, Cham.

Lee, D., Lim, C., \& Lim, J. (2009). Distance education. Seoul: Korea National Open University Press.

Li, S., Zhang J., Yu, C., \& Chen, L. (2017). Rethinking distance tutoring in e-learning environments: A study of the priority of roles and competencies of Open University tutors in China. The International Review of Research in Open and Distributed Learning. (In press).

Lim, Y. (2015). Restructuring types of higher education. Sejong: Minstry of Education, Korea

Lin, H. (2008). On the lack of regulations and regulation planning of distance education [J]. Modern Distance Education Research, 3.

Miles, M, B., \& Huberman, A. M. (1994). Qualitative data analysis: An expanded sourcebook. (2nd ed). Thousand Oaks, CA: Sage

Moore, M. G., \& Kearsley, G. (2011). Distance education: A systems view of online learning. (3rd ed.). Belmont, CA: Wadsworth.

Ozarslan, Y., \& Ozan, O. (2014). Yuksekogretimde uzaktan egitim programi acma sorunsali [The problem of opening a distance education program in higher education]. XIX. Turkiye'de Internet Konferansi, 27-29.

Resmi Gazete, 2000, "Enformatik Milli Komitesi Yonetmeligi" [Informatics National Committee Regulation], 1 Mart 2000 tarihli ve 23980 Sayili Resmi Gazete.

Resmi Gazete, 2000, "Enformatik Milli Komitesi Yonetmeligi [Informatics National Committee Regulation]", 1 Mart 2000 tarihli ve 23980 Sayili Resmi Gazete.

Rabinovich, T., Berthon, P., \& Fedorenko, I. (2017). Reducing the distance: financial services education in web-extended learning environments. Journal of Financial Services Marketing, 22(3), 126-131.

Sahin, I., \& Shelley, M. (2008). Considering students' perceptions: The distance education student satisfaction model. Educational Technology \& Society, 11(3), 216-223.

Simsek, H. (2007). Turkey. In J. J. F. Forest \& P. G. Altbach (Eds.), International handbook of higher education (reprinted Vol. 2, pp. 1003-1018). Dordrecht: Springer

Tesolin, A., \& Tsinakos, A. (2018). Opening real doors: Strategies for using mobile augmented reality to create inclusive distance education for learners with different-abilities. In Mobile and Ubiquitous Learning (pp. 59-80). Springer, Singapore.

YOK. (2014). Yuksekogretim Kurumlarinda Uzaktan Ogretime Iliskin Usul ve Esaslar [Procedures and Principles Regarding Distance Education in Higher Education Institutions], Retrieved December 23, 2019 from yok.gov.tr/Documents/Kurumsal/egitim_ogretim_dairesi/Uzaktan_ogretim/ yuksekogretim_kurumlarinda_uzaktan_ogretime_iliskin_usul_ve_esaslar.pdf

TBS. (2002). Bilgi Toplumuna Dogru, Taslak Rapor, Egitim calisma grubu [Towards the Information Society, Draft Report, Education working group ] (S. Korkut, Ed.). Turkiye Bilisim Surasi. 10-12 May 2002. Ankara

Yildirim, A., \& Simsek, H. (2006). Sosyal bilimlerde nitel arastirma yontemleri [Qualitative research methods in social scriences] (6. ed.). Ankara: Seckin Yayincilik.

Zawacki-Richter, O., \& Qayyum, A. (2019). Brief history of distance higher education. Olaf ZawackiRichter Adnan Qayyum Editors, 7.

Zhang, J. F., Zheng, S. H., \& Yu, D. (2012). Thoughts about legislation of modern long-distance education. Adult Education, 3. 